\title{
Francisco García del Cid Arias
}

\section{CARLES BAS i PEIRED}

Pg. Manel Girona 56, 4t 2a, 08034 Barcelona. E-mail: carlesbas@hotmail.com

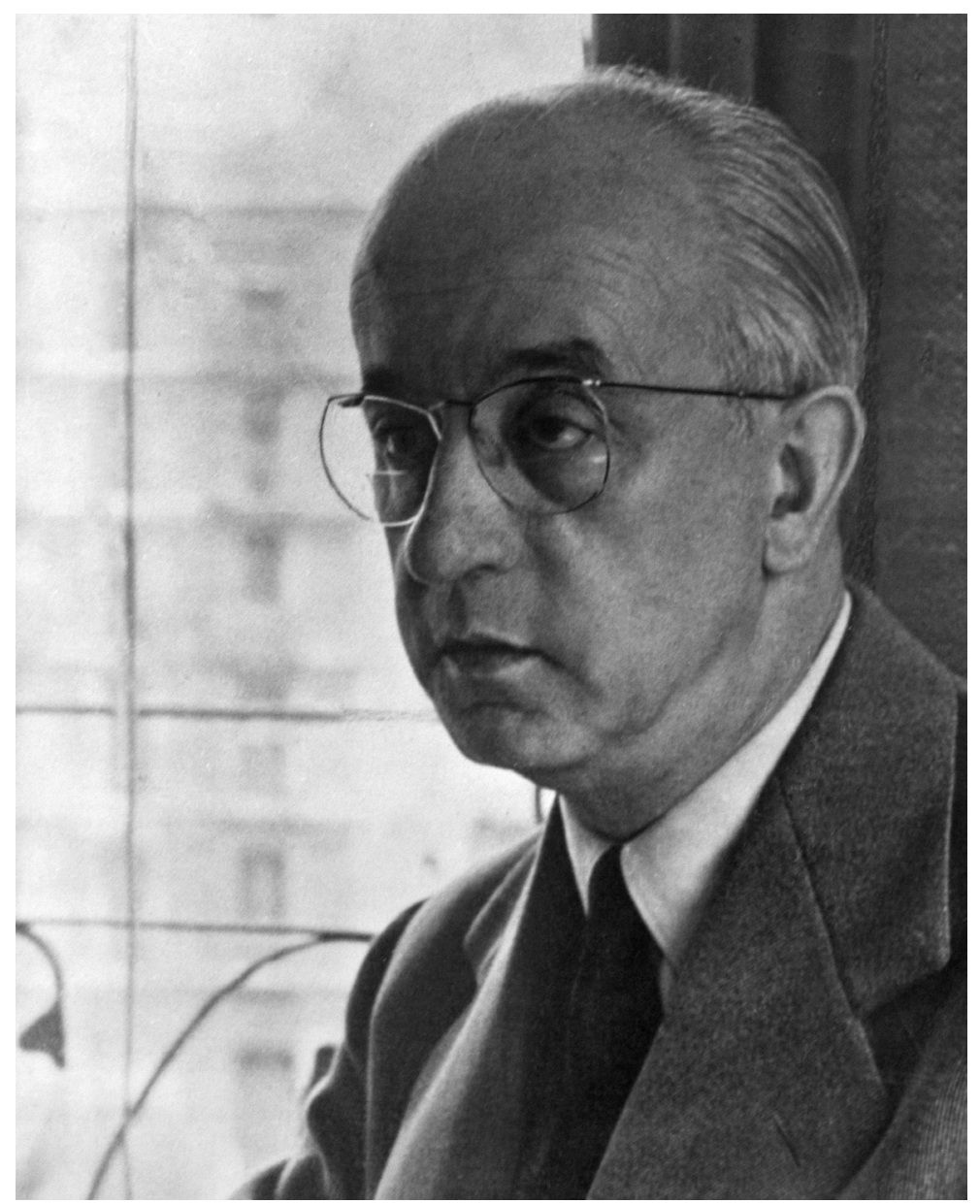

Francisco García del Cid y Arias was born in Málaga on September 2, 1897. His family moved to Tarragona when his father was appointed director of the local branch of the Bank of Spain. After graduating from high school in Tarragona in 1913, he studied natural sciences at the University of Barcelona. When he graduated in 1918, he became the assistant of Prof.
Josep Fuset, professor of Zoology and Biology at the University of Barcelona. At the same time he also taught a variety of courses, including experimental psychology at the University of Madrid.

Fuset was the successor of Prof. Odón de Buen, naturalist and oceanographer who, in 1912, founded the Spanish Institute of Oceanography (IEO, Instituto 
Español de Oceanografía). Presumably, Fuset directed the doctoral dissertation of García del Cid on labrid fish (Contribución al estudio de la fauna ictiológica española: lábridos de las costas de Cataluña y Baleares). In 1922 he defended his dissertation in Madrid, as was mandatory at the time. It is interesting to note that he used X-rays for researching the anatomy of the fish, which was particularly innovative for the time. That same year he took up a teaching job at the School of Agricultural Engineering of Barcelona (Escuela Superior de Agricultura de Barcelona).

To satisfy his appetite for more knowledge, he also studied medicine at the University of Barcelona and graduated in 1930. He then became technical assistant at the municipal forensic medicine laboratory. He specialized in nutrition and for several years shared his time between practising as a medical doctor and his teaching duties at the School of Agricultural Engineering. His teaching was related to research into insects, about which he wrote several scientific papers.

Prof. Fuset retired in 1941 after the Spanish Civil War (1936-1939) and a professorship position in entomology became available at the University of Barcelona. Dr. García del Cid won this position in 1942 . He taught a range of zoology subjects from arthropod and non-arthropod invertebrates to vertebrates.

In 1943 the Spanish National Research Council (CSIC, Consejo Superior de Investigaciones Científi- cas) established the Institute of Applied Biology (IBA, Instituto de Biología Aplicada) and nominated García del Cid as director, possibly due to his scientific activity in insect research. He founded the journal Publicaciones del Instituto de Biología Aplicada which contained abundant papers on applied agriculture related topics. At the same time he became a member of the CSIC board of trustees for Natural Sciences and Agriculture (Patronato Alonso de Herrera). During these years his research focused on xylophagous insects and general insect research. García del Cid travelled to international meetings and visited foreign research centres mainly in the areas of entomology, zoology and physiology.

By 1949 his interest for marine topics became more intense, perhaps fuelled by his contacts with the Stazione Zoologica di Napoli. At the same time, the new postwar government in Spain wanted to promote fisheries studies based more heavily on fundamental biology. The obvious context for promoting this would have been the IEO; however, it is possible that this institution was not favoured by the new government because some of its leaders sided with the loyalists before the war. Nevertheless, the IEO has always remained the Spanish national and international representative, especially in fisheries. In addition, Mr. Roig, a well-connected businessman from the east coast of Spain and a visionary interested in promoting fisheries related research, went to García del

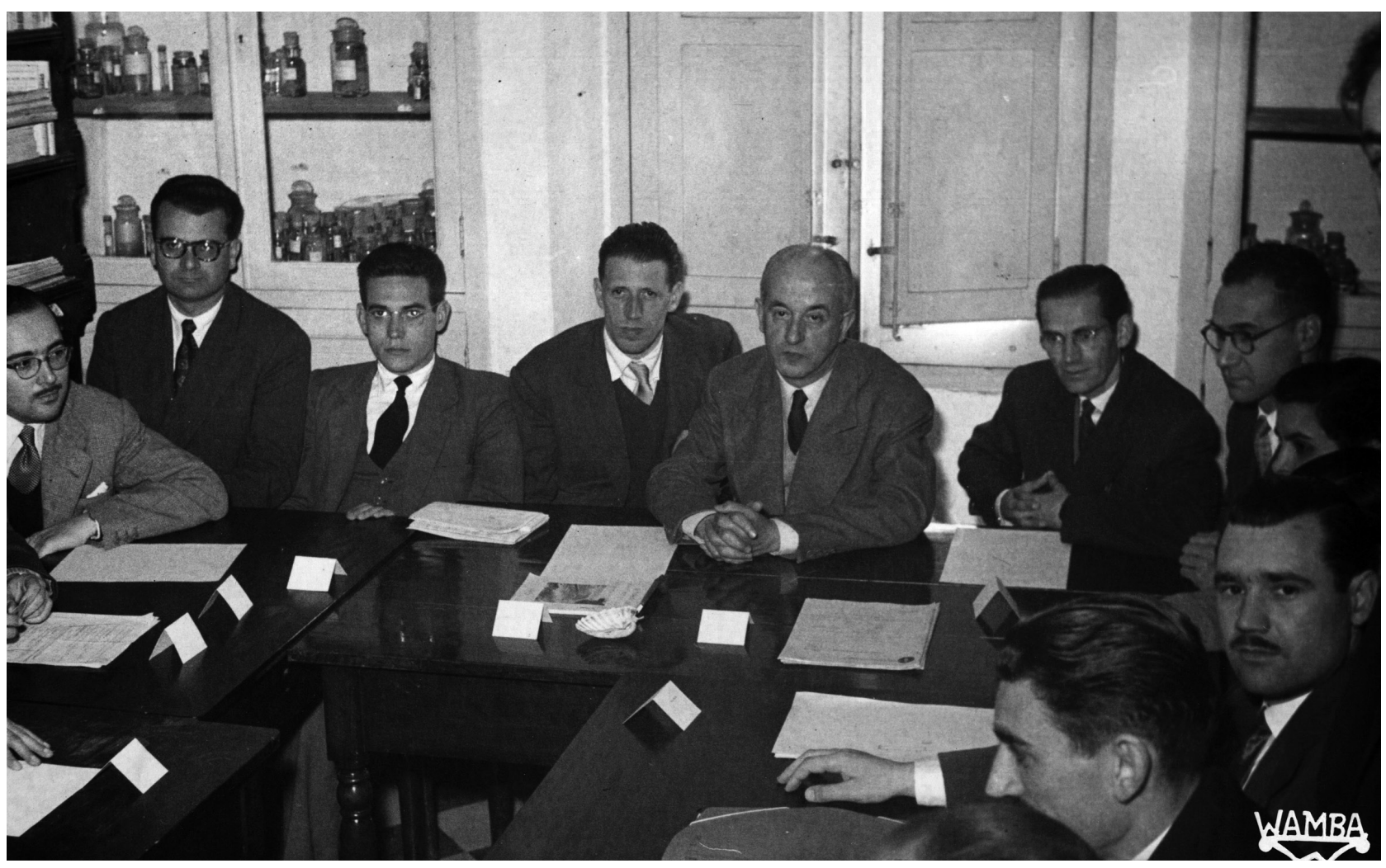

First meeting on Productivity and Fisheries held in the Grao de Castellón laboratory in 1954. From left to right around the table: Manuel Gómez-Larrañeta, Julio Rodríguez-Roda, Miquel Duran, Ramon Margalef, Francisco García del Cid, Buenaventura Andreu, Fernando Fraga, Concepción Seoane, Josep Selga and Carles Bas. 


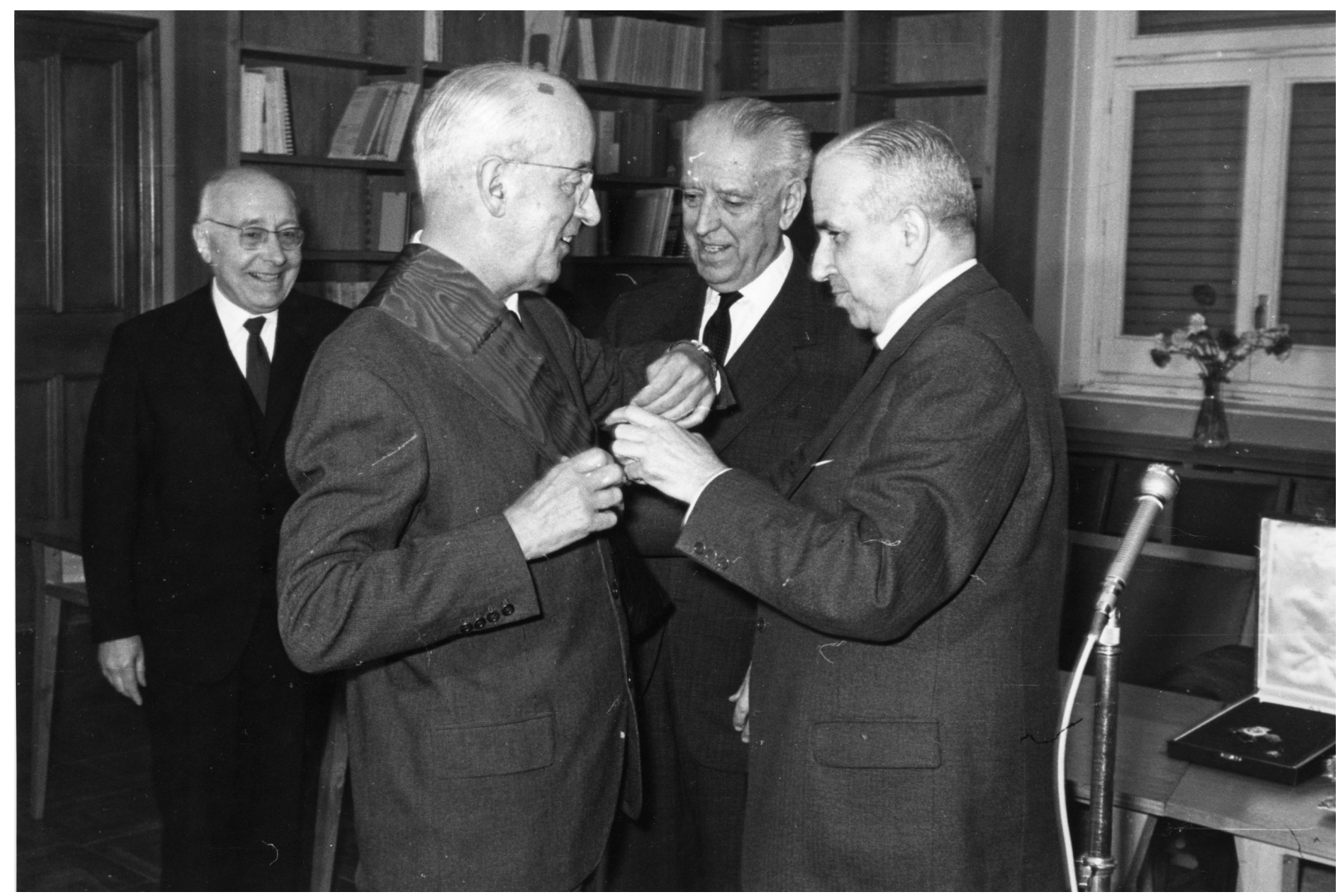

On the occasion of García del Cid's condecoration by Manuel Lora-Tamayo, Spanish minister of education (1962-1968).

Cid and Buenaventura Andreu asking for advice about establishing a fisheries research centre in Vinaroç that would also study general oceanography and plankton. All these circumstances led to the establishment of the Section of Marine Biology as a branch of the IBA on June 1, 1949. García del Cid recruited young scientists, among them Ramon Margalef, who had interests in plankton and was fast making a name for himself in science. The lab immediately showed strong research activity and scientific production. In 1951, the CSIC promoted the lab by establishing the Institute of Fisheries Research (IIP, Instituto de Investigaciones Pesqueras) and nominated García del Cid as its first director. That same year he founded the scientific journal Investigaciones Pesqueras.

García del Cid was director of the IIP until his tragic death. On the evening of October 21, 1965, he was run over by a car on Aribau Street just when he was leaving the University in Barcelona to go home. He was 68 years old.

During his years as director of the IBA and IIP, García del Cid carried on with his teaching activities at the university. He also directed, officially and unofficially, several doctoral dissertations, including those of Carles Bas, Julio Rodríguez-Roda, Manuel GómezLarrañeta and Pedro Suau, who would themselves become directors of different laboratories.
In 1952 he was appointed member of the Real Academia de Ciencias y Artes de Barcelona. His admission study, entitled La amenaza de los comejenes, was on a certain kind of termite. Although he focussed his attention on managing the marine sciences laboratories, for this event he chose a topic of his own earlier research activity. Most of his scientific production is related to entomology and applied zoology. He also translated a German book on biological theories and participated in writing an encyclopaedia on the sea. In 1964, García del Cid was awarded the Great Cross of the Order of Alfonso X el Sabio by the Spanish Head of State. A Spanish research vessel launched in 1979, which is still in service, bears his name.

\section{DIRECTORSHIP}

As a director of the IIP, García del Cid focused on managing the newly established institute. The first laboratories and offices were at the University of Barcelona, but soon the IIP expanded with facilities in Blanes, Vinaroç, Grao de Castellón, Vigo and Cádiz. He promoted interaction between the research groups at the different labs by organising periodic meetings on Productivity and Fisheries. These meetings were held periodically at different laboratories of the Institute and served to share and coordinate their research activity. 
The first field activities were carried out in Blanes in 1949, at facilities provided by Mr. Karl Faust, owner of the Botanical Garden Marimurtra in Blanes and an acquaintance of Margalef, who had begun sampling regularly at the site. After the training course in Blanes during the summer of 1949, Carles Bas stayed on alone in Blanes and Buenaventura Andreu started negotiations for carrying out research activities in a little residence in Grao de Castellón, further south down the Mediterranean coast. Other members of the IBA, such as Rodríguez-Roda and Gómez-Larrañeta, also transferred to Castellón. Margalef and others continued to carry out research at the laboratory of the Zoology Department of the University of Barcelona. Later, in 1951, Andreu became responsible for starting scientific activities in Vigo, a city on the Atlantic coast of Spain with an important fishing fleet and fishery industry. R. Toll was one of Andreu's earliest collaborators. In 1954, Rodríguez-Roda was transferred to Cádiz to start up a new laboratory. In Vinaroç, Mr. Roig together with the biologists Planas, Vives and Suau, continued working for some time before the lab became part of the new laboratory at Grao de Castellón. Suau and Gómez-Larrañeta, under the auspices of García del Cid, led a major project (El Plan Experimental de la Pesca de Arrastre de Castellón) from 1961 to 1966. This project was remarkable for the time because it applied population dynamics theory to the management of the trawl fishery with excellent results. The laboratory at Grao de Castellón also dedicated some of its efforts to aquaculture. Later on, after García del Cid had passed away, this would become crucial for changing the main scientific objectives of the lab from marine ecology and fisheries to aquaculture in the new facilities at Torre de la Sal.

In the meantime, a building for the Barcelona headquarters was being constructed. Initially, Dr. Gadea, who was García del Cid's assistant in his teaching activities and the secretary of the IBA, also gave management support to García del Cid. Buenaventura Andreu understood clearly the organisation of the different fisheries laboratories throughout Spain and took charge of setting up the laboratories in Grao de Castellón and
Vigo. At the same time, García del Cid greatly relied on the scientific criteria of a now internationally renowned Margalef, who was especially interested in plankton and marine systems ecology and who had started routine marine sampling series at several of the different laboratories. J. Selga was designated construction supervisor for the new headquarters in Barcelona and Dr. Arté was put in charge of organising the accompanying aquarium. Finally, in 1962 the new building of the IIP was inaugurated in Barcelona. The occasion was presided by the Spanish Head of State and García del Cid prepared thoroughly for the event, even publishing a booklet detailing the activities of the Institute.

Independently of his limited scientific legacy, García del Cid was an excellent teacher with broad general interests and knowledge in many different areas. He was a good-natured gentleman, with a kind, attentive and elegant character. He showed sincere interest in the vicissitudes of life of people around him. But above all, he had excellent creative management and scientific coordination skills, which he put to full use during his directorship of the IBA and especially the IIP. He established the IIP from very few initial resources and it became an internationally recognised scientific institution. Under his direction different laboratories were set up throughout Spain, several of which later expanded to become independent research institutes, and multidisciplinary research teams were established to address different aspects of marine and fisheries research.

\section{BIBLIOGRAPHY}

Anonymous. - 1966. In Memoriam. Invest. Pesq., 30: 7-8.

García del Cid, F. - 1952. La amenaza de los comejenes. Mem. Real Acad. Cienc. Art. Barcelona, 30: 485-524.

García del Cid, F. - 1957. Discurso de contestación. Mem. Real Acad. Cienc. Art. Barcelona, 32: 437-449.

Guerra, A. and R. Prego. - 2003. El Instituto de Investigaciones pesqueras. Estudios sobre la ciencia, 33. Consejo Superior de Investigaciones Científicas.

Lleonart, J. and F. Amat. - 2002. La recerca marina a Castelló. Institut d'Estudis Catalans.

Biography series ed.: F. Peters. 